\title{
Construction of Religious Identity in Pakpak Culture Community in Dairi District
}

\author{
Maimanah Angkat ${ }^{1}$, Katimin ${ }^{2}$, Anwarsyah Nur ${ }^{2}$ \\ ${ }^{1} \mathrm{Ph} . \mathrm{D}$ Student in State Islamic University of North Sumatera (UINSU), Medan, Indonesia \\ ${ }^{2}$ Lecturer in State Islamic University of North Sumatera (UINSU), Medan, Indonesia \\ mayangkat@gmail.com
}

\begin{abstract}
The aims of the study is to find out the construction of religious identity in pakpak culture community in Dairi district. The result of the study shows that there are three variations of dependence of Pakpak religion / belief and culture acculturation on other religions and cultures, the first group, traditional groups, in this group Pakpak's identity is still maintained and is dominated by parents and village communities who live far from pluralism occupation culture. Second, the bicultural group, this group is dominated by the Pakpak people who live in urban areas and who have received an established education, the behavior of this group is still thick with its Pakpak identity but has accepted differences with other religions and cultures. The three modern groups, in this group are dominated by Pakpak people who have long migrated to other areas and their Pakpak identity has changed. Of these three groups, the level of open personality was found to be very prominent for adolescents who became embryos of the development of Pakpak culture, such as the formation of identity, and interacting with peers.
\end{abstract}

Keywords: Construction of religious; identity; Pakpak culture; community.

\section{Introduction}

Every society has several concepts that are supernatural, spirits, gods or impersonal forces that are different from the others and in some meanings are superior to other forces that are used by humans as regulators of natural events and nature. And its activity is somehow capable of giving meaning to aspects of unusual human experience such as a phenomenon which makes logic unreasonable. In this case humans need religion which then gives birth to culture or vice versa is also a religious culture.

Ethnicity as one that sustains a sense of primordialism is often interpreted as a social group in a social or cultural system that has a certain meaning or position because of heredity, customs, religion, language, and so on. Members of an ethnic group have a common history (ancestry), language, value system, customs, and traditions. Overall, the ethnic group takes an important position in the social interaction of the intermingling process in all ethnic groups of indigenous peoples in the social community. However, sensitivity to cultural differences is needed because an approach that is too fast can cause internal conflict for ethnicity itself. In such circumstances, the knowledge and skills of local leaders are needed to improve behavior in sensitive areas is very important.

While religion is often returned to the equivalent of the word sangkrit "a" which means "no" and "gama" means "to go" when combined means not to go, remain in place, passed down from generation to generation ${ }^{1}$. In interpreting religion it seems very difficult to find a complete definition in a variety of words, according to Muhamin, there are three things that cause it to be difficult to give a definition of religion, first, because religious experience is a matter of mind and objective which is also individualistic; second, because in the study of religion people will be so passionate and emotional that it is difficult to give a definition; 
third, the conception of religion will be influenced by the purpose of the person who gives an understanding of religion itself. That is why religion becomes the basic part of one's primordial discussion.

Apart from the definition of religion from various perspectives of opinion that support it, the reality is the study of religion always refers to two sides of the reality of religion itself that cannot be denied, namely reality which has theological pattern, and reality that has historical-sociological pattern, or as a major cultural phenomenon ( grand culture) What is generally discussed about the existence of religion itself in the existence of human life that continues to grow and still requires religion as a basis for guidance in living life, and this is an interesting study of the attention of various groups in today's modern world.

Religion seen from the aspect of human life has a universal value of language and even exceeds the language itself that is internalized in human life itself. Therefore, any concept of human nature that is not encompassed by culture is only a fictional description of prehistoric humans whose authentic evidence cannot be found. Religion is a spirit value that makes the emergence of religious culture, whereas culture itself is the actualization of the internalization of religion itself.

\section{Review of Literature}

\subsection{General Description of PAKPAK Community}

The percentage of the population according to religion in Dairi Regency in 2010 can be broken down as follows: Islam: $20.28 \%$ (55,537 people); Protestants: 64.29\% (176,058 people); Catholic: $15.07 \%$ (41,269 souls); Buddha: 0.24\% (657 people); and Hinduism: $0.12 \%$ (329 people). The population of Dairi Regency at the end of June 2009 was 273,851 people with a sex ratio of $99.43 \%$. The number of villages / villages in Dairi Regency in 2009 were 169 units with an area of $1,927.82 \mathrm{~km}^{2}$ and a population density of 142 (souls $/ \mathrm{km}^{2}$ ), making the highest density level in Sidikalang District (669 people / $\mathrm{km}^{2}$ ) and Siempat Nempu District (320 inhabitants) / $\mathrm{km}^{2}$ ). While the lowest is Tanah Pinem District (46 inhabitants $/ \mathrm{km}^{2}$ ).

The Pakpak community has a number of values, beliefs, some are realized and some are not realized by the Pakpak community which is contained in a number of values, rules, taboos and ceremonies, especially activities that are directly related to nature such as in shifting cultivation, searching for resin, hunting, and gathering and managing forests that are related to traditional beliefs, in every place and kuta it is found or known that there are areas that are not to be disturbed by biotic and abiotic elements in it because they are considered to have supernatural powers including: rabag, caves, river banks and certain types of trees and animals that are considered to have meaning.

At first these places were made as a place of offering to the supernatural powers. Over time, the intensity of Pakpak people related to Hindu and Buddhist communities from India through international trade channels. This resulted in Pakpak dairi people who initially had a belief in "pelbegu / animism" gradually leading to the emergence of a new belief system with a combination of "pelbegu / animism with a Hindu and Buddhist ritual value system. but at this time even though generally they have embraced major religions such as Islam and Christianity, they are still considered sacred and have power so that if disturbed it can result in safety both directly and indirectly. 
Before the entry of Christianity and Islam by the Pakpak community in the dairi district, first the Pakpak dairi community knew the religion of "Pelbegu / Animism".

The presence of Hindu culture around the first century was followed by the arrival of Buddhism which combined with Hinduism and local beliefs and the entry of Islam in the 8th to 13th centuries increasingly brought its own style to the Pakpak dairi people's religions from initially syncretism of local elements with Hinduism and Buddhoism.

The style of trust of the Pakpak people initially believed in animism. In this period illustrated by the mystical values contained in the Pakpak clan, in this case there were Pitu (7) Sindalanen Pakpak teachers (ie Perbuahaji descendants) who were quite well-known with their mystical knowledge (respected shamans, feared and places of study or mysticism) known through a legend that is quite well known in the Pakpak area.

If Pitu Teacher Pakpak Sendalanen is united, then it is considered complete mysticism that people have learned in ancient times, which includes:

1. Raja Api (Raja Gagan) in the Pakpak Suak Pegagan area, is a shaman (datu) who has mysticism in the Power of Internal Sciences, which resembles a fire power (for example, called the Dipper of Fire, if hit by a blow it will burn or burn, Marulak Fist, that is, it is the person who hits him who experiences the effects of blows), the mysticism which is mastered and developed by the Fire King and his descendants is related to self-defense, fighting, and fighting against enemies.

2. Raja Angin in the Pakpak Suak Keppas area, is a shaman who has mysticism like wind power. If a strong wind blows (a typhoon) can knock down a strong and large. If the wind blows slowly, it will not be felt and cannot be seen, but they do exist. So it can suddenly the Shaman (who has this knowledge) is suddenly in front of our eyes.

3. Raja Tawar goes to Tanah Karo Simalem, is a shaman who has mysticism related to traditional herbal medicines. It has been proven that in the Karo Simalem area, the development of traditional herbal medicine, bone fracture treatment, burns and so on, which is sometimes more powerful than medical (medical) medicine.

4. Raja Lae or Lau or Lawe who went to Tanah Karo Simalem or Gayo-Alas areas. Lae $=$ lau = lawe means water (the language of the Toba tribe is called aek). Raja Lae is a shaman who has mysticism that can bring rain, prevent rain in one place or divert rain from one place to another (called Rain Pawang).

5. Raja Aji in the Pakpak Suak Simsim area around the sub-districts of the Kingdom, Salak and surrounding areas. Raja Aji is a shaman who has the flow of science of Making and Treatment of Aji-ajian diseases (uses, for example Aji Turtur, Gadam, Poison, and others).

6. Raja Besi in the Pakpak Suak Kellasen area, is a shaman who has mysticism related to tools made of iron. For example the science of resistance (invulnerability) is stabbed with a knife, immune to be sawed, protected from or immune to bullets from firearms, and others.

7. Raja Bisa in the Pakpak Suak Boang area, is a shaman who has mysticism related to the making and treatment caused by Can, such as snake venom, scorpions, centipedes, spiders, and others. 


\section{Discussion}

In Dairi district, there are a number of ethnic groups, including pakpak kepas and pakpak other than kepas and other ethnic groups which are the focus of the discussion in this study. These groups have their own cultural characteristics, the pakpak kepas culture is characterized as a culture of sipungka kuta which holds customary control in its lobbies, religion, tradition and family are the main constituents in this culture. Thus, the social relationships built in this study are based on the similarity of trust in family and friendship compared to the closeness of personal needs.

Because every individual Pakpak community in Dairi Regency depends on the family in general, and the family's reputation depends on the behavior of individual family members themselves. The concept of self-esteem and respect for others depends on the ethnic group, which operates in a cohesive, loving, warm unit, but at the same time suppresses personal care, opinion, experience, and needs. As a result, individual Pakpak people usually avoid overt expression of emotions because of the need to adjust to the collective norms of religious teachings and the surrounding culture as the main mechanism.

The construction of religious acculturation on Pakpak culture in Dairi Regency basically has the potential to be a local genius because it has been tested for its ability to survive with the following characteristics: (1) Able to withstand external culture; (2) Has the ability to accommodate elements of outside culture; (3) Has the ability to integrate elements of outside culture into native culture; (4) Having the ability to control; and (5) Able to give direction to cultural development.

Acculturation of religion and culture that is wrapped with aspects that affect changes in religion and culture, so for that it is very interesting to examine it more deeply as an effort to redefine the direction of religious and cultural acculturation in the Pakpak community in Dairi Regency as a step in the movement to find solutions faced by the community, especially the micro plains in Dairi and in the macro plains in Indonesia.

To see the situation, in this study taking Max Weber's theory, one way to analyze the situation is to isolate the variables in order to find the significance of each of these variables, after that then the significance of the variables is tested and then analyze the significance of the interdependence between the variables.

Reflecting on the theory, there are three crucial focuses in this study. First, interpreting the actions by understanding the motives of the religious behavior of the Papak community in Dairi Regency with the motives of the Papak community's cultural behavior in the Dairi Regency.

In this case, the inclusion of religion into the traditional culture of the Pakpak community in Dairi Regency has a variety of styles. First the behavior makes all religious teachings the same as culture. This behavior arises as a result of the condition of the Pakpak community who upholds its culture and is not accompanied by an understanding of adequate religious teachings, so it tends to make cultural actions wrapped in religious cults.

Secondly, the behavior of diving into and reviewing one's own culture in confrontation with religious teachings, in this behavior some Pakpak communities in Dairi district experience depression in addressing when there is a conflict between religious teachings and culture, in one situation done leaving religious teachings and following Pakpak culture and in other conditions follow the teachings of religion and leave their culture. 
Third, the behavior creates a new belief whose elements are taken from various religious and cultural teachings, this action requires that each adherent of religion and cultural practitioners feel that a portion of the religious and cultural teachings have been taken. This behavior is a continuation of the confrontation between the many religious and cultural teachings that appear around it, so that to facilitate the interaction with religious and cultural teachings requires acceptance of religious and cultural teachings and reformulate them in an action to follow in full the various teachings of religion and the culture.

Fourth, the behavior recognizes that the religion and culture practiced is the right one and tends to blame the behavior of others. In this behavior, one moves to choose the teachings of one religion and culture and denies the confrontation with the teachings of other religions and cultures and tries to make other people follow the pattern of Bergama and culture.

Fifth, the behavior that believes that religious and cultural behavior is the best and invites others to carry out the activities of the teachings of their respective religions and cultures and believes that between religion and culture in addition there are differences there are also equations. This behavior is an act of the importance of self-identity without denying the teachings of religious and diverse cultures around it.

\subsection{Systems of meaning in Pakpak religious ceremonies and customs in Dairi district.}

To see the systems of meaning that can be interpreted to make a decision or determine the situations that give rise to the individual actions of Pakpak people in the district of dairi in the religious ceremonies and customs of the Pakpak community in Dairi Regency can be described in the form of information regarding the needs of intent, policy, and ways measures taken to incorporate the influence of foreign religious and cultural teachings into the traditional beliefs and culture of the Pakpak community in Dairi Regency.

The process of acculturation in a traditional culture of the Pakpak Community in Dairi Regency influences the community's reaction to the Pakpak culture that appears in the form of a business or movement. Cultural originality is a very sensitive realm that at the same time has the possibility of conflicts of values, ethnicity and justice. Cultural actualization, grouped cultural behavior, may conflict with restrictions imposed by the traditions and cultural values of the Pakpak community in Dairi district, especially in sensitive areas such as family, friends, and expressions of feelings. Because in this area each sub-culture still holds the religious values and the collective culture of each group, this study has shown that they clearly agree on dissimilarities, but it does not rule out that special attention should be paid to the unique characteristics of each sub-group. Culture that is often associated with the level of acculturation.

Related to acculturation with the development needs and actualization of group culture as a collective culture of the Pakpak community in Dairi Regency, it is not possible to avoid acculturation between religions and cultures because the process is not only necessary but also effective in building a pluralistic society, although cultural conflicts are emerging today. , but can be overcome by acculturation process.

The relevance of cultural group factors other than self-disclosure in terms of acculturation, indeed the relationship between the expression of Papak's originality of culture and the matter of cultural acculturation of Pakpak with other cultures and the lack of differences in expression of affiliation indicate the existence of other driving factors 
operating in inter-religious and cultural processes that facilitate the occurrence of acculturation process.

\subsection{An open personality in a cultural group}

Self-actualization is the key to group cultural acculturation, group culture acculturation is defined as acceptance and rejection as a specific thing intended to help solve the development of various existing problems and form original culture in conformity with other cultural inputs. This can be distinguished from traditional stakeholder groups aimed at prevention and education, and from government groups, which are designed as those who manage severe behavior.

Acculturation groups are very prominent for adolescents who are embryos of Pakpak cultural development, such as the formation of identity, building independence, and dealing with peers. In the group process, Pakpak teenagers with various problems that exist in the current context are aware of their various problems to look at a globalized world of culture that is becoming universal. For that they need to get to know themselves in order to interact well, both with group members and feedback given by others. They have the power of group cohesiveness and increase the ability to overcome various problems together.

From some differences in the comparison of the three ethnic groups in Dairi district, namely the Pakpak, Toba, and Karo ethnic groups, the Toba teenagers will show the highest level of disclosure (in this case self, family, friends, and feelings) the second position is pakpak and the next position is Karo. Likewise, we consider that the Pakpak tribe in Dairi district are in the best position responding to cultural openness, the later toba and Karo tribes are the last, while the intermingling of cultural groups the best position is the ethnic Toba then pakpak and very few of the Karo Ethnics, while in terms of research As gender is investigated, women generally produce opinions that are exactly the same as boys in the level of openness to the culture of other groups.

\section{3 grouping of Pakpak people based on religious and cultural behavior}

In Pakpak culture there are generally three cultural variations between groups as seen from their acculturation dependence on other cultures, the group among others, traditional, bicultural, and modern. Papak traditional cultural identity is the general cultural identity of Papak people in rural areas, where people live with traditional values that apply in their family life and social life. Whereas bicultural cultural identity is generally found among the middle class such as people who have enjoyed education and are even more likely to be modern and almost lose their cultural identity and abandon their cultural norms. While the modern identity group is a group that has migrated from its lobbies to other regions, so that sometimes it has been forgotten that it has forgotten its identity as part of the Papak community itself.

Differences in the level of acculturation between Pakpak and other cultures are found in the most contrasting Sidikalang city which is considered bicultural. The possibility that occurs is due to the intensity of frequent contact with outside cultures, cultural diversity, ethnicity of the population coupled with an established level of community education. So that it raises openness to accept each other and fill culture for the common good.

The difference between Pakpak people and other cultures is also reflected in the attitude of acceptance and rejection with other cultures, Papak people tend to believe in external natural factors (sipungka kuta lobu) as a factor causing the naturalization of other cultures to 
their culture which as a whole is considered too extreme in addressing other cultures, but slowly that effort cannot bias the process of cultural acculturation to occur without realizing it naturally. They do it themselves as an answer to the situation and intensity of social relations that occur, so that it can survive in the short term while looking at various possible solutions to these conditions.

Whereas the traditional acculturation process can generally be described by the intensity of verbal relationships that occur, so that the addition of insight is often experienced in this group, so that the outreach of the acculturation process occurs dialectically, but due to social inequality and changes in social status and family transformation Papak people tend to be satgnans because they do not have a platform in campaigning for their cultural originality.

On this basis, cultural restrictions on the Pakpak community among the teenagers of the Pakpak community will reveal information about the personality of the Pakpak culture that is lacking compared to other cultures, especially in matters relating to the family system and close friends. Comparison of attitudes to culture among young Papuans compared to adolescents from other tribes in the district. Dairi is more likely to lead to self-disclosure in groups, in the comparison of the two dimensions of family and friendship; young Papak teenagers get an unfavorable attitude towards disclosure of their identity as ethnic Papak culture.

\section{Conclusion}

The motives of the Pakpak community's religious behavior in Dairi Regency with the cultural behavior motives of the Pakpak people in the Dairi Regency. First the behavior makes all religious teachings the same as culture. Second, behavior to dive in and review old beliefs and cultures in confrontation with new religions and cultures, third, behavior creates a new belief whose elements are taken from various religious and cultural teachings, fourth, behavior recognizes that the religion and culture practiced is the right one and tends to blame other people's behavior. Fifth, the behavior that believes that religious and cultural behavior is the best and invites others to carry out the activities of the teachings of their respective religions and cultures and believes that between religion and culture in addition there are differences there are also equations.

Seen from behavioral dependence, there are three variations of dependence of Pakpak religion / belief and culture acculturation on other religions and cultures, the first group, traditional groups, in this group Pakpak's identity is still maintained and is dominated by parents and village communities who live far from pluralism occupation culture. Second, the bicultural group, this group is dominated by the Pakpak people who live in urban areas and who have received an established education, the behavior of this group is still thick with its Pakpak identity but has accepted differences with other religions and cultures. The three modern groups, in this group are dominated by Pakpak people who have long migrated to other areas and their Pakpak identity has changed. Of these three groups, the level of open personality was found to be very prominent for adolescents who became embryos of the development of Pakpak culture, such as the formation of identity, and interacting with peers. 


\section{References}

Ridwan Lubis, (2015) Sosiologi Agama; Memahami Perkembangan Agama Dalam Interaksi Sosial, Jakarta: Prenada Media Group.

Ridwan Lubis, (2015) Agama dan Perdamaian; Pengalaman Keberagamaan di Indonesia, Ciputat: Referensi.

Muhaimin, (1989) Problematika Agama Dalam Kehidupan Manusia, Jakarta: Kalam Mulia. Kurniawan, (1990) Jejak Hindu di Tanah Batak, Bogor:Kurnia..

Lister Berutu, and Nurbani Padang, (2007)Tradisi dan Perubahan, Medan:Grasindo Monoratama.

Lister Berutu, Juniar Banurea, (2006) Pertuturen Pakpak : istilah dan adat sopan santun kekerabatan pada masyarakat Pakpak, Medan : Grasindo Monoratama.

Ery Soedewo, (2010) "Jejak Keindiaan (Hindu-Buddha) dalam Kebudayaan Pakpak", dalam Berkala Sangkhakala, vol. xiii no. 26, September.

Poerbatjaraka, Agastya di Nusantara, (2002) Jakarta: Yayasan Obor Indonesia.

Claude Guillot, (2001) Lobu Tua: Sejarah Awal Barus, Jakarta: Yayasan Obor Indonesia.

Ludvik Kalus, (2008) Inskripsi Islam Tertua di Indonesia, Jakarta: Kepustakaan Populer Gramedia dan Ecole Francaise d ${ }^{\text {ee }}$ Extrem Orien dan Forum Jakarta-Paris.

Christine Dobbin, (1987) Islamic Revivalism in a Changing Peasant Economy:Central Sumatra 1784-1847, London: Curzon Press.

Jan S. Aritonang, (2004)Sejarah Perjumpaan Kristen dan Islam di Indonesia, Jakarta: Gunung Mulia..

Max Weber, (2012) The Sociology of Religion, Terj. Yudi Susanto, Yogyakarta: IRCiSoD. 